\title{
A QUEDA DOS CORPOS PARA ALÉM DO QUE SE VÊ: CONTRIBUIÇ̃̃ES DAS IMAGENS ESTROBOSCÓPICAS E DA VIDEOANÁLISE PARA A ALFABETIZAĈ̣̃O CIENTÍFICA
}

\author{
Marco Adriano Dias ${ }^{1 *}$ \\ https://orcid.org/ 0000-0001-5486-9869 \\ Deise Miranda Vianna ${ }^{2 *}$ \\ https://orcid.org/0000-0001-5846-0841 \\ Paulo Simeão Carvalho $0^{3 * *}$ \\ https://orcid.org/0000-0002-5381-955X
}

RESUMO: Apresentamos os resultados de uma pesquisa que vem desenvolvendo intervenções didáticas investigativas que utilizam como recursos imagens estroboscópicas e videoanálise, buscando confirmar se elas contribuem para a alfabetização científica. Imagens estroboscópicas e videoanálise permitem um ensino em diversos contextos, pois com sua utilização pelo professor, os alunos estudam movimentos reais que foram anteriormente filmados e transformados em material didático. Considerando o potencial desses recursos para a aprendizagem científica, investigamos de que forma sua utilização numa intervenção sobre a queda dos corpos colabora para a alfabetização científica. $\mathrm{Na}$ análise dos diálogos entre os alunos durante a construção dos argumentos em resposta à situação problema proposta pelo professor, identificamos um grande número dos indicadores de alfabetização científica.

Palavras-chave: Imagem Estroboscópica; Videoanálise; Ensino Investigativo; Alfabetização Científica.

\section{LA CAÍDA DE LOS CUERPOS PARA MÁS ALLÁ DE LO QUE VES: CONTRIBUCIONES DE LAS IMÁGENES ESTROBOSCÓPICAS Y DEL VIDEO-ANÁLISIS PARA EL ALFABETISMO CIENTÍFICO}

'Doutor em Ciências:
Ensino de Ciências pelo
Instituto Oswaldo Cruz (IOC).
Professor Pesquisador do
Instituto Federal
do Rio de Janeiro.
E-mail:< marco.dias@ifrj.edu.br $>$.
Grupo PROENFIS.
'.Doutora em Educação
pela Universidade de
São Paulo (USP). Professora
Pesquisadora do Instituto
de Física da Universidade Federal
do Rio de Janeiro, (UFRJ)
e do Programa de Pós Graduação
em Ensino de Biociências e Saúde
do Instituto Oswaldo Cruz (IOC).
E-mail: < deisemv@if.ufrj.br $>$.
Grupo PROENFIS.
... Doutor em Física
pela Universidade do
Porto (UP). Professor
Pesquisador do Departamento
de Física e Astronomia da
Faculdade de Ciências da
Universidade do Porto (IFIMUP).
E-mail: < psimeao@fc.up.pt $>$.

RESUMEN: Presentamos los resultados de una investigación que ha desarrollado intervenciones didácticas investigativas que utilizan como recursos imágenes estroboscópicas y vídeo-análisis, buscando confirmar si estas contribuyen para el alfabetismo científico. Imágenes estroboscópicas y videoanálisis permiten una enseñanza en contextos diversos, pues con su utilización por el maestro, los alumnos estudian movimientos

\footnotetext{
${ }^{1}$ Instituto Federal do Rio de Janeiro, Nilópolis, RJ - Brasil.

${ }^{2}$ Universidade Federal do Rio de Janeiro, Rio de Janeiro, RJ - Brasil

${ }^{3}$ Universidade do Porto, Porto - Portugal
} 
reales que fueron anteriormente filmados y convertidos en material didáctico. Considerando el potencial de estos recursos para el aprendizaje científico, investigamos de qué manera su utilización en una intervención acerca de la caída de los cuerpos contribuye para el alfabetismo científico. En el análisis de los diálogos entre los alumnos durante la construcción de los argumentos respuesta a la situación problema propuesta por el maestro, identificamos un gran número de los indicadores de alfabetismo científico.

Palabras clave: Imagen estroboscópica; Video-análisis; Enseñanza Investigativa; Alfabetismo Científico

\section{FALLING BODIES FURTHER THAN THE EYES CAN SEE: CONTRIBUTIONS OF STROBE IMAGES AND VIDEO ANALYSIS FOR SCIENTIFIC LITERACY}

ABSTRACT: We present the results of a research that has been developing investigative didactic interventions with the use of strobe images and video analysis, and trying to confirm how they contribute to scientific literacy. Strobe images and video analysis allow teaching in different contexts, because with their use by the teacher, students investigate real movements that were previously filmed and transformed into didactic material. Considering the potential of these resources for scientific learning, we investigate how their use in an intervention on the fall of bodies contributes to scientific literacy. In the analysis of the dialogues among students during the construction of the arguments in response to the problem-situation proposed by the teacher, we identified a large number of indicators of scientific literacy.

Keywords: Strobe Image; Video Analysis; Research Teaching; Scientific Literacy. 


\section{CONSIDERAÇÕES INICIAIS}

O ensino da queda dos corpos é um tema tradicionalmente presente nos currículos de ensino de Física, tanto nos da educação básica quanto nos do ensino superior. Por se tratar de um fenômeno corriqueiro, é um assunto no qual os estudantes têm conhecimentos prévios e, mesmo depois da escolarização formal, há casos em que persistem as concepções aristotélicas como, por exemplo, de que o tempo de queda sempre depende da massa.

Por ser um assunto clássico nas aulas de Física, quando não é ensinada de forma descritiva com apoio do livro didático acompanhado de uma demonstração prática, a queda dos corpos é ensinada com enfoque experimental no laboratório didático tradicional, caso a instituição de ensino conte com essa estrutura. Assim, quando a queda dos corpos é abordada experimentalmente no laboratório tradicional, os roteiros fechados adotados para as práticas demandam pouco esforço cognitivo dos alunos, ficando estes com o papel de confirmar modelos preconcebidos a partir de experimentos reproduzidos em equipamentos industrializados, com pouca interação entre si e pouca reflexão sobre a própria prática científica.

A fim de oferecer uma metodologia alternativa àquela do laboratório tradicional, utilizamos recursos de vídeo, imagens estroboscópicas e videoanálise para o ensino do movimento de queda de diferentes esferas na sala de aula, com um enfoque no ensino por investigação e baseado na observação sistemática do movimento com os recursos citados. A escolha da metodologia de ensino por investigação se deu por acreditarmos que essa modalidade permite ao aprendiz desenvolver um conjunto de habilidades importantes para a vida em sociedade, levando em conta sua atuação cidadã com criticidade e responsabilidade, ou seja, se trata de uma metodologia de ensino capaz de promover a alfabetização científica.

Em nossa concepção, um ensino que busca a promoção da alfabetização científica deve permitir que o aprendiz desenvolva as habilidades relacionadas aos três Eixos Estruturantes da Alfabetização Científica, organizados por Sasseron e Carvalho (2011, p. 75-76). O primeiro é o eixo referente à "compreensão básica de termos, conhecimentos e conceitos científicos fundamentais", o segundo referente à "compreensão da natureza das ciências e dos fatores éticos e políticos que circundam sua prática" e o terceiro relativo ao "entendimento das relações existentes entre ciência, tecnologia, sociedade e meio ambiente" (SASSERON; CARVALHO, 2011, p. 75-76).

Imagens estroboscópicas e videoanálise contribuem para a alfabetização científica? A fim de responder a essa questão, realizamos uma pesquisa qualitativa com alunos do ensino médio, na qual buscamos identificar nas interações discursivas evidências da construção do conhecimento científico. $\mathrm{Na}$ medida em que os Indicadores de Alfabetização Científica propostos por Sasseron e Carvalho (2008) puderam ser identificados na fala dos alunos durante suas interações discursivas, se encontrou evidência de que a construção do conhecimento científico estava em curso com a promoção da alfabetização científica. 


\section{IMAGENS ESTROBOSCÓPICAS E VIDEOANÁLISE COMO RECURSOS DIDÁTICOS}

Todo corpo em movimento pode ser filmado para, com o vídeo digital, serem produzidas as imagens estroboscópicas e feito um estudo sistemático com a videoanálise. Esses recursos - vídeo digital, imagem estroboscópica (IE) e videoanálise (VA) - são utilizados para o planejamento e operacionalização de intervenções didáticas investigativas, cuja eficiência para a alfabetização científica (AC) é pesquisada neste trabalho.

A origem das IE está nas antigas fotografias estroboscópicas, que foram propostas como material didático do Physical Science Study Committee (PSSC). Essas fotografias, também chamadas de fotografias de múltipla exposição, eram produzidas em laboratório a partir do registro, numa única fotografia, do movimento de um corpo em diversos instantes ao longo da sua trajetória (Figura 1). A vantagem de se utilizar esse tipo de fotografia como material didático era o fato de a captura de imagens ocorrer numa frequência constante. Com isso, ficava registrado na fotografia a posição do corpo em movimento em diversos instantes, permitindo, a partir de medidas simples com uma régua, o estudo sistemático do movimento. Com essas informações e com os valores da massa do corpo, podia-se analisar a dinâmica e a cinemática de um determinado fenômeno.

A proposta metodológica de utilização das fotografias estroboscópicas pelo PSSC como material didático apontava no sentido de substituir os experimentos realizados em caros aparatos experimentais e, por isso, inacessíveis à maioria das escolas, pelas fotografias com as quais o estudante fazia medidas, construía tabelas e gráficos, buscava regularidades, tudo em sala de aula.

Figura 1. Fotografias estroboscópicas presentes no PSSC
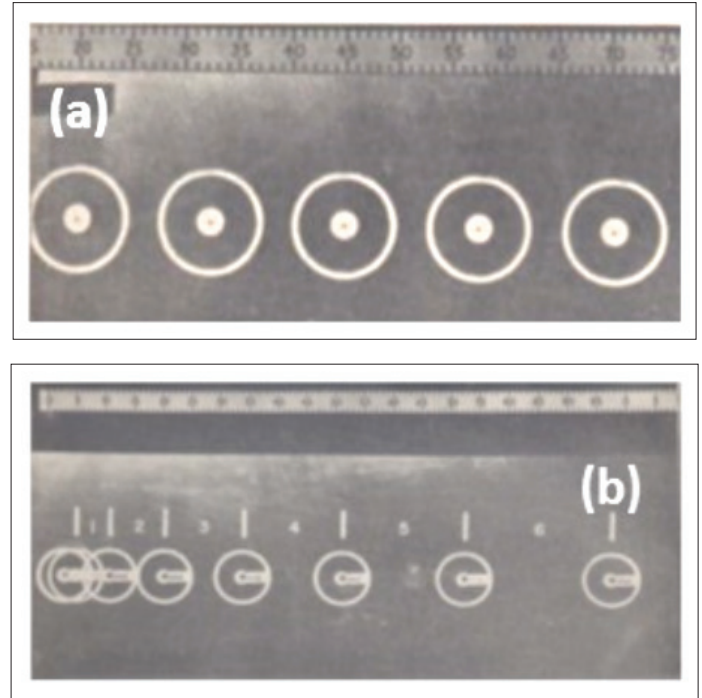

Legenda: (a) - disco se movimenta com velocidade constante; (b) - movimento com aceleração constante;

Fonte: PSSC, 1965. 
O livro Projeto Brasileiro para o Ensino de Física (CANIATO, 1979) também propôs como recurso didático a utilização de fotos estroboscópicas para o ensino e aprendizagem de diversos movimentos. Na Figura 2 estão algumas dessas fotografias, disponíveis também no blog do autor.

Figura 2. Fotografias do blog do professor Rodolpho Caniato
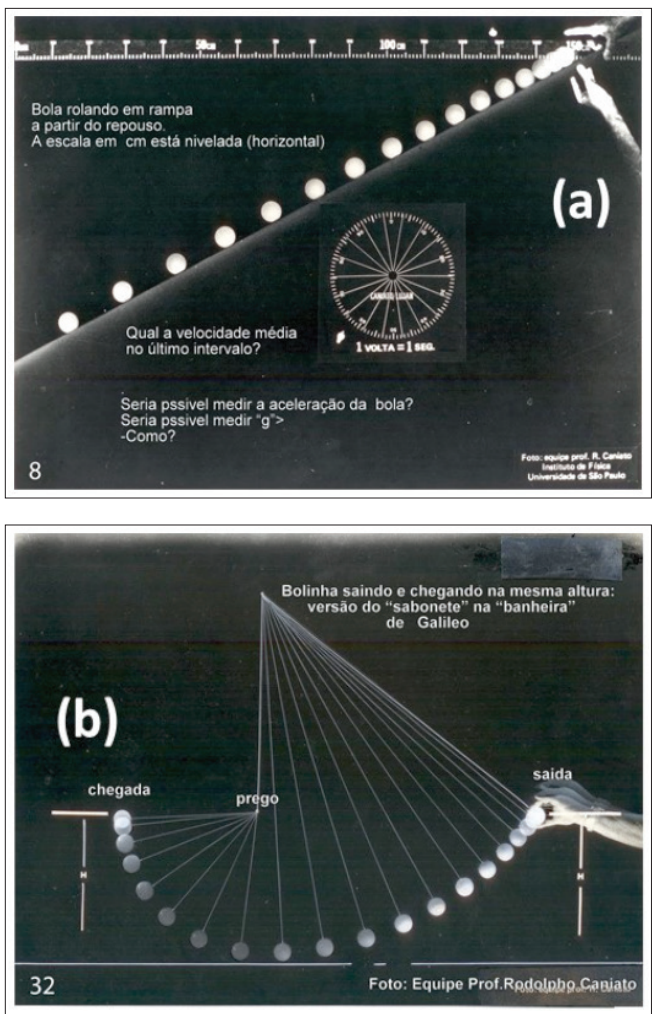

Legenda: (a) - esfera em um plano inclinado; (b) - um pêndulo oscila.

Fonte: CANIATO, 2011.

Em cada uma das fotografias estroboscópicas da Figura 2 há informações necessárias para que possam ser utilizadas como um recurso didático ao ensino experimental. Na Figura 2a, por exemplo, além de uma régua na parte superior da fotografia, há um relógio cujo movimento do ponteiro também ficou registrado, o que indica que o intervalo de tempo entre duas posições consecutivas é sempre constante. Os problemas também são propostos na própria fotografia, como podemos observar nas duas fotos da Figura 2.

Com o advento da imagem digital, a produção de vídeos foi popularizada. Conforme foi apresentado por Dias, Barros e Amorim (2009), a partir de um vídeo digital e um PC com aplicativos gratuitos podem ser produzidas IE. Essa técnica tem a vantagem de permitir que os movimentos estudados sejam aqueles que ocorrem no cotidiano dos alunos, como as práticas esportivas, os transportes, os animais etc. A Figura 3 mostra IE de esferas em movimentos regulares e de atletas durante execução de movimentos corporais. 
Figura 3. IE de esferas e atletas em movimento
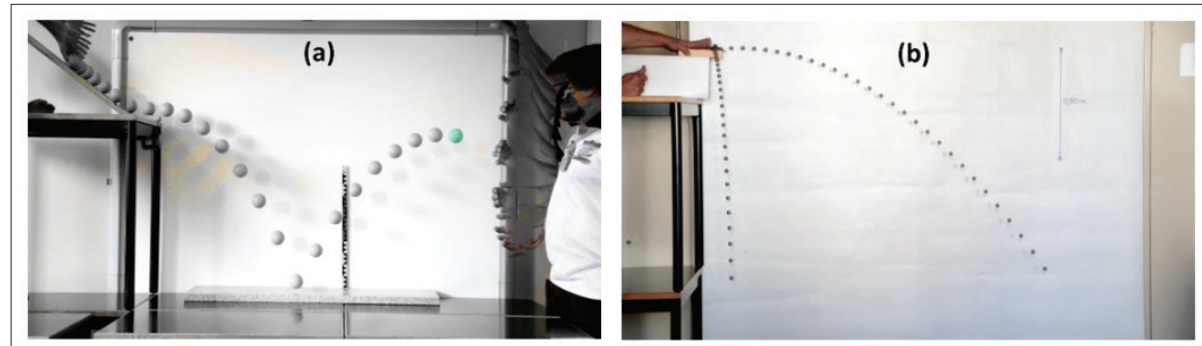

(c)
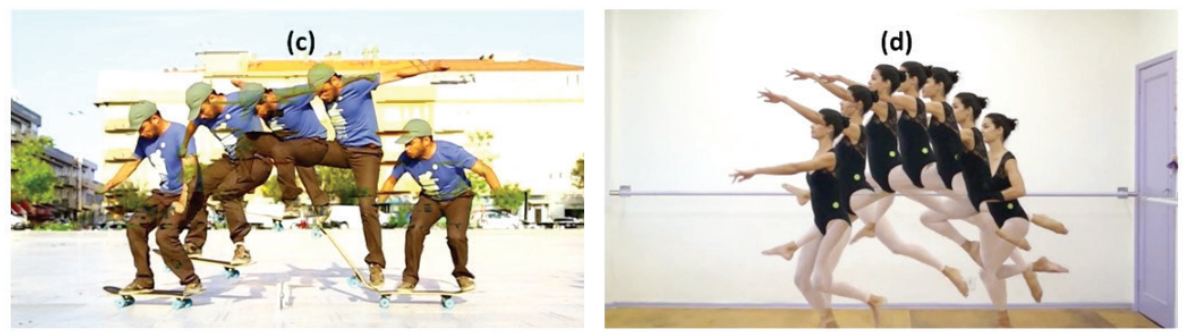

Legenda: (a) - IE de uma esfera abandonada de uma canaleta inclinada; (b) - lançamento simultâneo de duas esferas; (c) - manobra ollie da modalidade skateboard (DIAS; CARVALHO; VIANNA, 2016); (d) - salto Grand Jeté do ballet (DIAS et al., 2017).

Fonte: 0 autor, 2017.

Outro recurso de vídeo disponível para o estudo sistemático do movimento é a VA, que consiste na análise do movimento de corpos a partir de vídeos. Brown (2008) apresentou o software livre Tracker, de sua autoria. Uma vez que o vídeo é importado para o Tracker, as posições do corpo em movimento são auferidas com o mouse e os dados de posição em cada instante são automaticamente organizados em uma tabela, a partir da qual pode-se esboçar gráficos e fazer diversos tipos de ajustes a modelos matemáticos (lineares, parabólicos ou exponenciais, entre outros).

Muitos pesquisadores têm utilizado essa ferramenta para descrever movimentos complexos, os quais antes do advento do Tracker eram difíceis de ser estudados empiricamente (JESUS; BARROS, 2014; JESUS; SAZAKI, 2015). Há ainda a proposta de utilização da videoanálise associada à utilização de modelagem computacional (BROWN, 2009) para o estudo da acústica (CARVALHO et al, 2013), da óptica (RODRIGUES; CARVALHO, 2014) e para o estudo de movimentos pouco convencionais em sala de aula (DIAS; CARVALHO; RODRIGUES, 2016; DIAS; CARVALHO; VIANNA, 2016; DIAS et al, 2017).

A Figura 4 mostra a interface do Tracker, na qual percebemos o cenário em que ocorre o movimento (nesse caso um lançamento oblíquo de uma esfera), o referencial escolhido (linhas perpendiculares de cor avermelhada) e a calibração do fator de escala entre as dimensões do vídeo e o cenário real (segmento azul com $30,00 \mathrm{~cm}$ ). O próprio aplicativo Tracker oferece um recurso que permite a produção da imagem estroboscópica. Percebemos na Figura 4 os dados organizados em tabela e a representação gráfica da posição y em função do tempo. 
A Queda dos Corpos para além do que se vê: Contribuições das imagens

Estroboscópicas e da Videoanálise para a Alfabetização Científica

Figura 4. Interface do aplicativo Tracker para a análise do movimento de uma esfera lançada obliquamente.

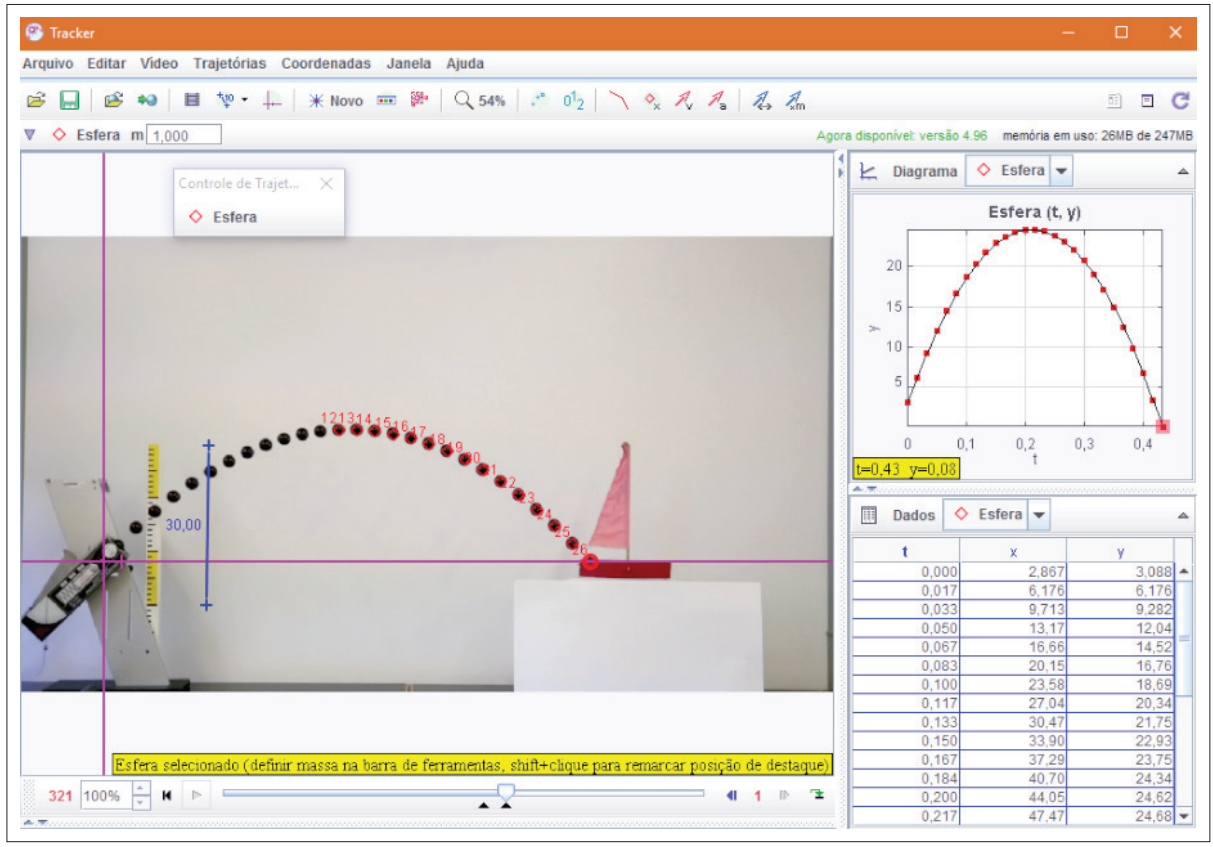

Fonte: 0 autor, 2017.

\section{INTERVENC̣ÕES DIDÁTICAS DE INVESTIGAC̣ÃO BASEADAS EM VÍDEO}

Propomos uma intervenção didática que utiliza como referencial de ensino as Sequências de Ensino Investigativas (CARVALHO, 2013) e a estratégia interativa Prever-Observar-Explanar (WHITE; GUNSTONE, 1992). As Sequências de Ensino Investigativas (SEI) permitem que as aulas ocorram como um processo de investigação e a estratégia Prever-Observar-Explanar (POE) permite a interação dos alunos com um fenômeno a partir da demonstração feita pelo professor e, por isso, se trata de uma estratégia didática que pode ser utilizada para sistematizar a discussão entre os alunos sobre um fenômeno em estudo com a obtenção de bons resultados, como confirmaram Tao e Gunstone (1999), Kearney (2004), Kuçukozer (2008), Rakkapao et al (2014) e Santos e Sasaki (2015).

Portanto, o que chamamos de intervenções didáticas de investigação baseadas em vídeo, trata-se de uma metodologia de ensino que utiliza os recursos IE e VA com estratégia de ensino investigativo SEI e interativo POE para a resolução de problemas reais (MALHEIRO; FERNANDES, 2015). Nossas escolhas buscam transformar a sala de aula numa comunidade de aprendizagem, na qual os alunos aprendam Ciências estabelecendo, desestabelecendo e reestabelecendo o conhecimento, numa dinâmica em que suas concepções prévias sejam valorizadas. Ou seja, numa dinâmica hands-on, minds-on e hearts-on, favorecendo assim a interação social, social-on (BASSOLI, 2014). Dessa maneira, esperamos alcançar nosso objetivo geral que é criar oportunidades para a formação de um aluno crítico, com cultura científica e com espírito investigativo, ou seja, um aluno alfabetizado cientificamente 
O Quadro 1 mostra as interseções das etapas da estratégia POE e das etapas propostas nas SEI.

Quadro 1. Interseções entre os referenciais de ensino para Intervenções Didáticas de Investigação Baseadas em Vídeos

\begin{tabular}{|c|l|}
\hline Estratégia POE & \multicolumn{1}{c|}{ Proposta SEI } \\
\hline \multirow{2}{*}{ Previsão } & $\begin{array}{l}\text { Proposição do Problema. } \\
\text { Descrição da demonstração que ocorrerá no vídeo projetado para toda } \\
\text { a turma e proposição do Problema; } \\
\text { Discussão entre os alunos em grupo para resolução do Problema; } \\
\text { Sistematização e formulação de uma resposta para o grupo; } \\
\text { Escrever e desenhar a previsão sistematizada pelo grupo. }\end{array}$ \\
\hline $\begin{array}{c}\text { Observação } \\
\text { (Exibição do } \\
\text { Vídeo) }\end{array}$ & $\begin{array}{l}\text { Discussão entre os alunos no grupo para validar, invalidar e revalidar a } \\
\text { formulação da resposta na Previsão; } \\
\text { Sistematização e formulação de uma resposta pelo grupo; }\end{array}$ \\
\hline Explanação & $\begin{array}{l}\text { Escrever e diagramar a explanação cientificamente correta do } \\
\text { fenómeno ou acontecimento. } \\
\text { Texto de Sistematização do conhecimento (material didático impresso } \\
- \text { livro) } \\
\text { Contextualização Social ou Aprofundamento do Conteúdo feita pelos } \\
\text { alunos. }\end{array}$ \\
\hline
\end{tabular}

Fonte: 0 autor, 2017.

\section{METODOLOGIA DE PESQUISA: A BUSCA POR INDICADORES DE ALFABETIZAÇÃO CIENTÍFICA}

Apresentamos os resultados da pesquisa cuja hipótese é que as IE e a VA são recursos com potencial para promover a AC. Os sujeitos da pesquisa foram alunos da primeira série do ensino médio, etapa escolar em que a maioria dos alunos tem o primeiro contato com a disciplina Física. A intervenção ocorreu em uma escola pública de ensino médio-técnico no município de Nilópolis, no Rio de Janeiro.

Em sala de aula, a turma foi dividida em seis grupos de até seis integrantes. O professor apresentou a situação problema e, a partir desse instante, as interações discursivas entre os alunos nos grupos foram registradas em áudio com gravadores digitais para a posterior transcrição das falas e busca por indicadores de AC. Os indicadores de AC constituem um conjunto de habilidades e competências que têm semelhanças com o fazer ciência, ou seja, com a prática investigativa. Sasseron e Carvalho (2008, p. 338) destacam que os indicadores são "competências comuns desenvolvidas e utilizadas para a resolução, discussão e divulgação de problemas".

A coleta de dados gerou seis arquivos de áudio, um para cada grupo, com cerca de duas horas de diálogos cada. Os áudios foram auscultados e um dos grupos, escolhido aleatoriamente, teve seus diálogos transcritos. As etapas da intervenção estão delineadas no Quadro 2. 
A Queda dos Corpos para além do que se vê: Contribuições das imagens

Estroboscópicas e da Videoanálise para a Alfabetização Científica

Quadro 2. Delineamento das etapas da intervenção didática na qual foram coletados os dados

\begin{tabular}{|c|c|c|}
\hline Etapa & Objetivo & Ações \\
\hline 1 & $\begin{array}{l}\text { Ganhar a atenção da } \\
\text { turma }\end{array}$ & $\begin{array}{l}\text { Organização dos grupos, apresentação do tema de } \\
\text { estudo e distribuição do material }\end{array}$ \\
\hline \multirow{3}{*}{2} & \multirow{3}{*}{$\begin{array}{l}\text { Proposta do estudo da } \\
\text { queda de duas esferas } \\
\text { de massas e diâmetros } \\
\text { diferentes, quando } \\
\text { abandonadas de uma } \\
\text { mesma altura e num } \\
\text { mesmo instante }\end{array}$} & $\begin{array}{l}\text { Prever: os grupos discutem e formulam as suas } \\
\text { previsões baseadas no que eles acham que vai } \\
\text { acontecer. }\end{array}$ \\
\hline & & $\begin{array}{l}\text { Observar: o professor reproduz o vídeo quantas vezes } \\
\text { forem necessárias para que os alunos registrem as } \\
\text { suas observações; os alunos comparam as suas } \\
\text { previsões com a observação do vídeo; o professor } \\
\text { exibe a imagem estroboscópica a fim de enriquecer } \\
\text { a observação dos alunos. }\end{array}$ \\
\hline & & $\begin{array}{l}\text { Explicação: os alunos formulam suas explicações } \\
\text { por escrito, primeiro na forma qualitativa e depois, } \\
\text { se conveniente, na forma quantitativa. }\end{array}$ \\
\hline 3 & $\begin{array}{l}\text { Sistematização do } \\
\text { conhecimento }\end{array}$ & Os grupos leem suas explicações para a turma \\
\hline \multirow{3}{*}{4} & \multirow{3}{*}{$\begin{array}{l}\text { Proposta de } \\
\text { substituição da esfera } \\
\text { pequena da etapa } 2 \\
\text { por uma ainda menor; } \\
\text { estudo da queda dessas } \\
\text { esferas }\end{array}$} & $\begin{array}{l}\text { Prever: os grupos discutem e formulam as suas } \\
\text { previsões baseadas no que eles acham que vai } \\
\text { acontecer. }\end{array}$ \\
\hline & & $\begin{array}{l}\text { Observar: o professor reproduz o vídeo para que } \\
\text { os alunos registrem as suas observações, quantas } \\
\text { vezes forem necessárias; os alunos comparam } \\
\text { as suas previsões com a observação do vídeo; o } \\
\text { professor exibe a imagem estroboscópica a fim de } \\
\text { enriquecer a observação dos alunos. }\end{array}$ \\
\hline & & $\begin{array}{l}\text { Explicação: os alunos formulam suas explicações } \\
\text { por escrito, primeiro na forma qualitativa e depois, } \\
\text { se conveniente, na forma quantitativa. }\end{array}$ \\
\hline 5 & $\begin{array}{l}\text { Sistematização do } \\
\text { conhecimento }\end{array}$ & Cada grupo lê a sua explicação para a turma \\
\hline 6 & Finalização & $\begin{array}{l}\text { Discussão em grande grupo sobre os resultados } \\
\text { obtidos; dá-se a conciliação das ideias e a escrita } \\
\text { da interpretação do fenômeno pelos alunos, usando } \\
\text { linguagem científica. }\end{array}$ \\
\hline
\end{tabular}

Fonte: 0 autor, 2017. 
Foram duas proposições de problemas feitas pelo professor, nas quais esferas de massas e diâmetros diferentes seriam abandonadas aos pares, no mesmo instante e de uma mesma altura. As proposições foram realizadas com auxílio de imagens projetadas, como as da Figura 5.

Figura 5. Imagens utilizadas para auxiliar na descrição da atividade para os alunos

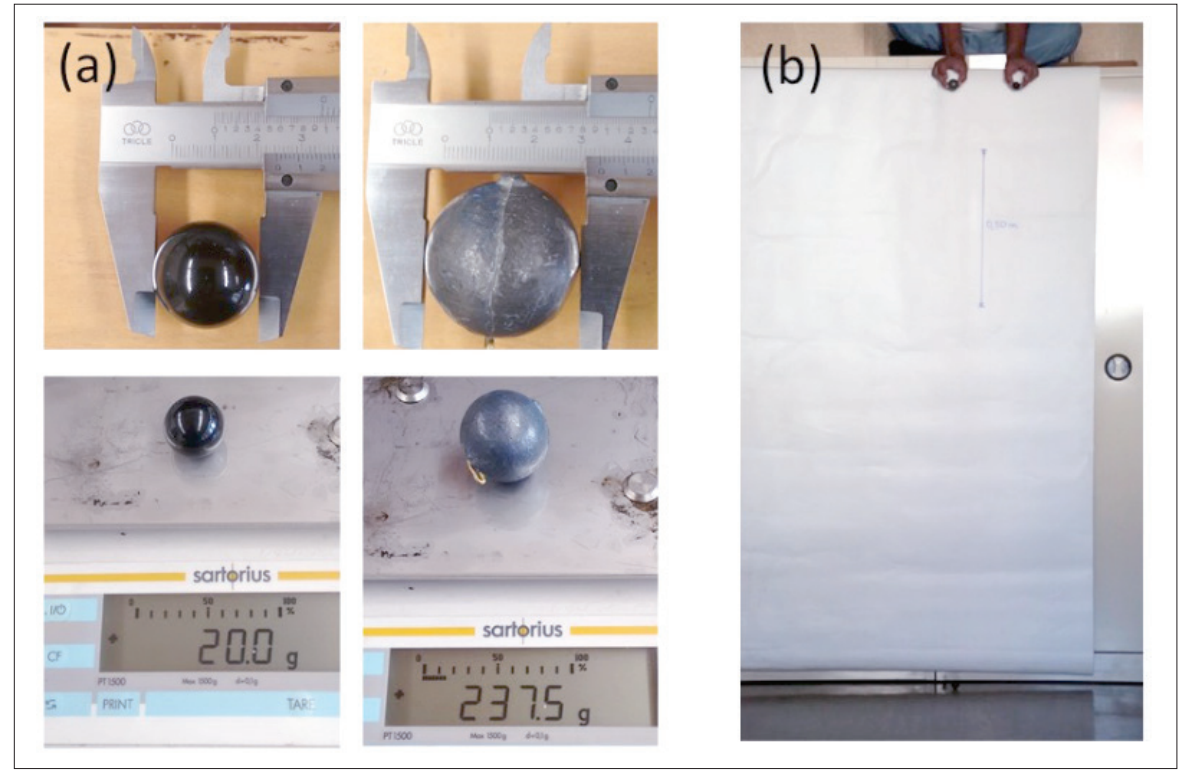

Legenda: (a) - informações de massa e diâmetro para caracterizar as diferenças entre as esferas; (b) - cenário com o local de onde foi gravado o vídeo.

Fonte: 0 autor, 2017.

A seguir, apresentamos a primeira proposição de problema, a transcrição dos episódios de ensino que surgiram durante a etapa de solução pelos alunos e os Indicadores de AC nos episódios.

\section{PROPOSIC̣ÃO 1}

Parte 1 - Apresentação da situação problema, proposição da questão de investigação e formulação das previsões

Conforme o Quadro 1, de acordo com a estratégia POE, a situação problema foi inicialmente descrita e a questão a responder foi cuidadosamente formulada para que os alunos fizessem coletivamente suas previsões. E, de acordo com as SEI, se deu a distribuição do material, a proposição do problema pelo professor e a solução do problema (previsão) pelos alunos. Assim, a situação problema colocada foi: duas esferas de tamanhos diferentes, uma pequena com diâmetro $2,4 \mathrm{~cm}$ e massa $20 \mathrm{~g}$ e outra maior com diâmetro 3,4cm e massa 237,5g (Figura 5a), serão abandonadas de uma mesma altura no mesmo instante, conforme a imagem projetada (Figura 5b). Como podemos comparar os movimentos das duas esferas? 
O Quadro 3 mostra a transcrição do episódio inicial de ensino de um grupo da turma.

Quadro 3. Transcrição do episódio inicial de ensino

\begin{tabular}{|c|c|c|c|}
\hline Turno & Fala & Descrição & Indicador de AC \\
\hline 18 & $\begin{array}{l}\text { Lays: Abandonando } \\
\text { simultaneamente as } \\
\text { duas esferas... }\end{array}$ & $\begin{array}{l}\text { A aluna abandona um frasco de } \\
\text { cola escolar branca e sua tampa, } \\
\text { num mesmo instante, a fim de } \\
\text { reproduzir a queda de dois corpos } \\
\text { diferentes }\end{array}$ & $\begin{array}{l}\text {-Levantamento } \\
\text { de hipóteses } \\
\text {-Teste de } \\
\text { hipóteses }\end{array}$ \\
\hline 19 & $\begin{array}{l}\text { Carla: Não gente, } \\
\text { eu sei que vão cair } \\
\text { os dois [ao mesmo } \\
\text { tempo] }\end{array}$ & $\begin{array}{l}\text { A aluna utiliza conhecimentos } \\
\text { anteriores de que a massa não } \\
\text { influi na queda dos corpos }\end{array}$ & $\begin{array}{l}\text {-Levantamento } \\
\text { de hipóteses }\end{array}$ \\
\hline 20 & $\begin{array}{l}\text { Lays: Porém ó! } \\
\text { Abandonando } \\
\text { simultaneamente as } \\
\text { duas esferas como } \\
\text { podemos comparar } \\
\text { os movimentos de } \\
\text { cada uma... }\end{array}$ & $\begin{array}{l}\text { A aluna reproduz novamente a } \\
\text { queda dos dois corpos e verifica } \\
\text { que caem ao mesmo tempo }\end{array}$ & $\begin{array}{l}\text {-Teste de } \\
\text { hipóteses }\end{array}$ \\
\hline 21 & $\begin{array}{l}\text { Marcos: A esfera } \\
\text { mais pesada vai } \\
\text { chegar primeiro. }\end{array}$ & $\begin{array}{l}\text { O aluno traz para o grupo a } \\
\text { concepção de que corpos mais } \\
\text { pesados caem mais rapidamente } \\
\text { do que corpos mais leves }\end{array}$ & $\begin{array}{l}\text {-Levantamento } \\
\text { de hipóteses } \\
\text {-Raciocínio } \\
\text { proporcional }\end{array}$ \\
\hline 22 & Lays: Ó, vou soltar. & & $\begin{array}{l}\text {-Teste de } \\
\text { hipóteses }\end{array}$ \\
\hline 23 & $\begin{array}{l}\text { Marcos: o que eu falei } \\
\text { que a mais pesada } \\
\text { vai cair primeiro. }\end{array}$ & $\begin{array}{l}\text { O aluno chama a atenção do grupo } \\
\text { para a queda das esferas proposta } \\
\text { pelo professor, descartando a } \\
\text { possibilidade da queda da cola e } \\
\text { da sua tampa ser um fenômeno } \\
\text { análogo }\end{array}$ & $\begin{array}{l}\text {-Levantamento } \\
\text { de hipóteses } \\
\text {-Raciocínio } \\
\text { proporcional }\end{array}$ \\
\hline
\end{tabular}

Fonte: 0 autor, 2017.

$\mathrm{Na}$ análise da transcrição desse primeiro episódio de ensino percebemos o envolvimento dos alunos com a formulação de uma previsão. Além dos indicadores de AC presentes nos diálogos, percebemos que os alunos trazem seus conhecimentos anteriores. Quando Carla diz "eu sei que vão cair os dois", percebemos um conhecimento prévio escolarizado de que, em queda livre, a massa do corpo não influi no movimento. Por outro lado, quando Marcos diz "a esfera mais pesada vai chegar primeiro”, fica evidente a presença da concepção alternativa de que a massa influi em todo o movimento de queda. Percebemos 
nesse episódio que os alunos se envolveram com a solução do problema proposto. Essa dimensão afetiva é importante para a aprendizagem científica.

\section{Parte 2 - observação do fenômeno a partir do vídeo e da IE}

Na estratégia POE, após a formulação das previsões, o fenômeno deve ser demonstrado para que os alunos registrem suas observações. Nas SEI, os alunos validam, invalidam ou revalidam a resposta da previsão.

A demonstração da queda das esferas foi feita a partir do vídeo, através do qual percebe-se que uma pessoa abandona as duas esferas com suas mãos (Figura 5b) e nota-se que as esferas atingem o chão no mesmo instante. $\mathrm{O}$ vídeo foi reproduzido várias vezes por solicitação dos alunos. Porém, a IE revelou algo que os olhos não foram capazes de perceber no vídeo: as esferas não atingiram o chão no mesmo instante. E mais: a esfera que atingiu o chão primeiro foi a menor, hipótese que não havia sido levantada na fase da previsão. A IE da queda das duas esferas de massas e diâmetros diferentes, abandonadas por uma pessoa, atingindo o solo em instantes diferentes está representada na Figura 6.

\section{Figura 6. IE}

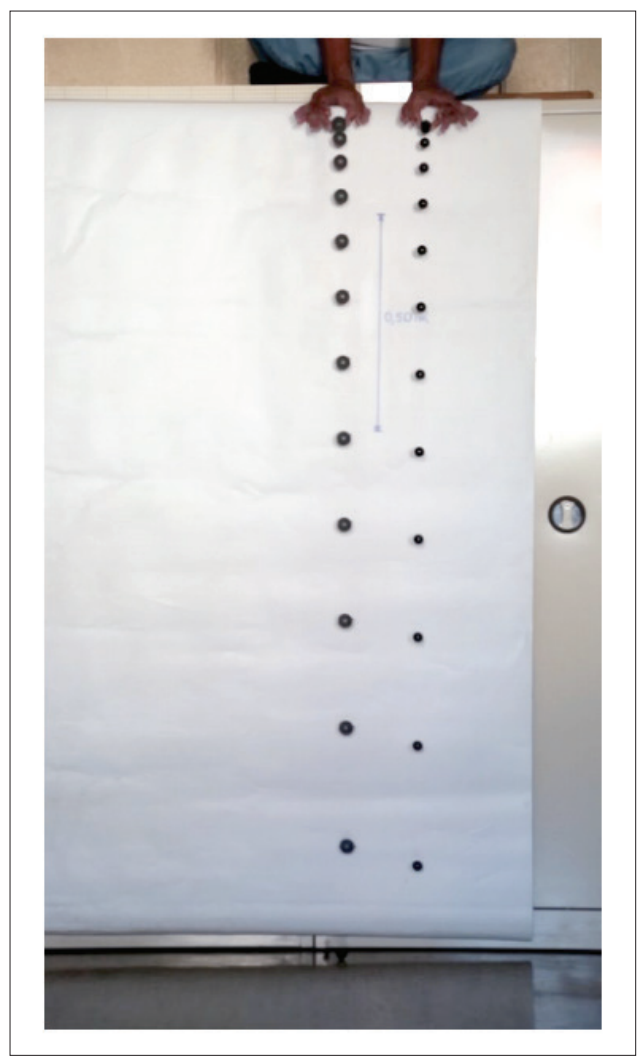

Fonte: 0 autor, 2017. 
No Quadro 4 está a transcrição do segundo episódio de ensino para o mesmo grupo de alunos, relacionado à etapa da observação.

Quadro 4. Transcrição do segundo episódio de ensino

\begin{tabular}{|c|c|c|c|}
\hline Turno & Fala & Descrição & Indicador de AC \\
\hline 64 & $\begin{array}{l}\text { Lays: Gente, presta atenção: } \\
\text { quando a gente assiste ao } \\
\text { vídeo, a gente acha que os dois } \\
\text { caem no mesmo intervalo de } \\
\text { tempo. Pela foto estroboscópica } \\
\text { a gente percebe que a bolinha } \\
\text { de menor massa, ela alcança } \\
\text { primeiro o chão. E aí, o que a } \\
\text { gente coloca? Isso? }\end{array}$ & $\begin{array}{l}\text { A aluna reflete sobre } \\
\text { como descrever a } \\
\text { observação, se com o } \\
\text { resultado do vídeo ou da } \\
\text { imagem estroboscópica }\end{array}$ & $\begin{array}{l}\text {-Organização de } \\
\text { informações } \\
\text {-Seriação de } \\
\text { informações }\end{array}$ \\
\hline 65 & $\begin{array}{l}\text { Carla: Será que ele não soltou a } \\
\text { bolinha primeiro? Porque esses } \\
\text { erros acontecem. Senão você } \\
\text { veria as duas caírem ao mesmo } \\
\text { tempo no chão. }\end{array}$ & $\begin{array}{l}\text { Carla levanta a hipótese } \\
\text { da não simultaneidade } \\
\text { do abandono das esferas } \\
\text { pelo professor. }\end{array}$ & $\begin{array}{l}\text {-Levantamento } \\
\text { de hipóteses } \\
\text {-Organização de } \\
\text { informações }\end{array}$ \\
\hline 66 & Lays: Professor! & Lays recorre ao professor. & \\
\hline 67 & João: Depende né? Do atrito. & $\begin{array}{l}\text { João introduz a ideia de } \\
\text { uma nova variável influir } \\
\text { no movimento das bolas }\end{array}$ & -Justificativa \\
\hline 68 & $\begin{array}{l}\text { Carla: É verdade. Mas assim } \\
\text { seria a bolinha mais pesada } \\
\text { chegar mais rápido. }\end{array}$ & & $\begin{array}{l}\text { - Justificativa } \\
\text {-Explicação } \\
\text {-Raciocínio } \\
\text { proporcional }\end{array}$ \\
\hline
\end{tabular}

Fonte: 0 autor, 2017.

No turno 64 fica registrado que Lays se depara com uma 'realidade' que contrapõe seu conhecimento prévio: trata-se de um confronto entre o que ela achava que aconteceria e o que é observado. Essa dicotomia fez com que surgissem duas explicações: no turno 65, Carla chama atenção para o fato de que o professor poderia ter abandonado as esferas em instantes ligeiramente diferentes, o que seria imperceptível a partir do vídeo, mas revelado na IE; e no turno 67, João considera a hipótese de as esferas estarem interagindo com o ar, hipótese refutada no turno 68, por Carla. Vale ressaltar que nenhuma das duas possibilidades foi considerada pelo professor durante o planejamento da intervenção. A sugestão da não simultaneidade no abandono (turno 65) e a consideração da resistência do ar na queda (turno 67) são consequências da observação da IE, não da observação do vídeo, o que revela uma atitude crítica dos alunos perante a observação dos fenômenos. Isto apenas foi possível porque lhes foi dada a oportunidade para confrontar e discutir os resultados em grupo.

Como percebemos nas transcrições dos próximos episódios de ensino, as interações discursivas foram no sentido de corroborar uma das duas hipóteses. 
Parte 3: Explicando o observado

De acordo com a estratégia POE, após a observação do fenômeno, os alunos explicam com riqueza de detalhes a observação. Nas SEI, neste mesmo momento, ocorre a discussão entre os alunos em grupo para resolução do Problema, a sistematização e formulação de uma resposta para o grupo e as ações de escrever e diagramar a previsão sistematizada pelo grupo.

De uma maneira geral, a observação refutou as previsões de todos os grupos, o que enriqueceu as interações para formulação de uma explanação (terceira etapa na metodologia POE). Foi preciso reproduzir outras vezes o vídeo, fazer medidas na fotografia projetada na tela, consultar o livro didático, levantar novas hipóteses, testá-las, construir argumentos, formular, reformular e etc. A sala de aula se transformou em um ambiente interativo, colaborativo e investigativo (minds-on, hands-on, hearts-on, social-on). A seguir, apresentamos a transcrição de um episódio de ensino desta fase da intervenção:

Quadro 5. Transcrição do terceiro episódio de ensino

\begin{tabular}{|c|c|c|c|}
\hline Turno & Fala & Descrição & Indicador de AC \\
\hline 71 & $\begin{array}{l}\text { Marcos: Quanto } \\
\text { mais leve o corpo, } \\
\text { mais rápido chega? }\end{array}$ & $\begin{array}{l}\text { O aluno se depara com uma observação } \\
\text { que contrapõe seu conhecimento prévio }\end{array}$ & $\begin{array}{l}\text { - Levantamento de } \\
\text { hipóteses }\end{array}$ \\
\hline 72 & $\begin{array}{l}\text { João: Quanto } \\
\text { menos atrito mais } \\
\text { rápido chega. }\end{array}$ & $\begin{array}{l}\text { Observando a Imagem Estroboscópica } \\
\text { João descarta a possibilidade de que } \\
\text { a resistência do ar dependa apenas da } \\
\text { massa, fazendo uma generalização. }\end{array}$ & $\begin{array}{l}\text {-Classificação de } \\
\text { informação } \\
\text {-Raciocínio lógico } \\
\text {-Raciocínio } \\
\text { proporcional } \\
\text {-Justificativa }\end{array}$ \\
\hline 73 & $\begin{array}{l}\text { Lays: Mas é a } \\
\text { resistência do ar. }\end{array}$ & $\begin{array}{l}\text { Lays corrige o termo atrito usado } \\
\text { pelos colegas. Não associa o atrito à } \\
\text { resistência do ar. }\end{array}$ & -Explicação \\
\hline 74 & $\begin{array}{l}\text { João: Sim, } \\
\text { resistência do ar. Eu } \\
\text { cismo que é atrito. }\end{array}$ & $\begin{array}{l}\text { João evidencia pouca confiança no uso } \\
\text { dos termos resistência do ar ou atrito; } \\
\text { contudo sabe que se trata de uma força } \\
\text { contrária ao movimento do corpo no ar. }\end{array}$ & $\begin{array}{l}\text {-Classificação de } \\
\text { informação }\end{array}$ \\
\hline 75 & $\begin{array}{l}\text { Lays: Gente, deixa a } \\
\text { Carla falar. }\end{array}$ & & \\
\hline 76 & $\begin{array}{l}\text { Carla: Se fosse a } \\
\text { resistência do ar a } \\
\text { bolinha grande ia } \\
\text { chegar mais rápido. }\end{array}$ & $\begin{array}{l}\text { Carla utiliza um raciocínio de } \\
\text { proporcionalidade inversas entre } \\
\text { a resistência do ar e as dimensões } \\
\text { das esferas. Não fica claro se ela } \\
\text { estabelece uma relação com as massas } \\
\text { das bolas. }\end{array}$ & $\begin{array}{l}\text {-Organização de } \\
\text { informaç̃̃es } \\
\text {-Previsão } \\
\text {-Raciocínio lógico } \\
\text {-Raciocínio } \\
\text { proporcional }\end{array}$ \\
\hline 77 & $\begin{array}{l}\text { João: Quanto maior } \\
\text { o corpo maior a } \\
\text { resistência do ar. }\end{array}$ & $\begin{array}{l}\text { Refuta a Carla com raciocínio } \\
\text { proporcional a partir da observação } \\
\text { da Imagem Estroboscópica, } \\
\text { considerando as dimensões da esfera e } \\
\text { desconsiderando as massas. }\end{array}$ & $\begin{array}{l}\text {-Organização de } \\
\text { informações } \\
\text {-Previsão } \\
\text {-Raciocínio lógico } \\
\text {-Raciocínio } \\
\text { proporcional }\end{array}$ \\
\hline
\end{tabular}

Fonte: 0 autor, 2017. 
Inicialmente havia duas previsões: no turno 19, Carla previu que as esferas cairiam juntas, o que indicou que a aluna tinha conhecimento sobre o conceito de queda-livre; no turno 21, Marcos previu que a "mais pesada" cairia primeiro, previsão que pode ter relação tanto com a concepção de que a massa influi na queda livre quanto com o conhecimento de que, considerando a resistência do ar, ela atuaria mais sobre a esfera "mais leve" e com isso ela deveria chegar depois da esfera maior (até aqui não tivemos dados que revelassem que o aluno considerou as dimensões da esfera para a resistência do ar).

De um lado, após a observação das quedas no vídeo e na IE, Carla continuou a descartar a influência da resistência do ar, conforme a transcrição do turno 76, fundamentada no seu conhecimento de que, caso a resistência do ar tivesse influência nos movimentos de queda, ela deveria ser menor sobre a "bolinha grande" e, assim, ela cairia primeiro; com isso a aluna qualificou seu argumento para manter a previsão de que não houve simultaneidade no abandono.

Por outro lado, os alunos que consideravam a resistência do ar tiveram também seu qualificador no turno 77, quando João colocou que quanto maior o corpo maior a resistência do ar, incluindo a grandeza diâmetro da esfera como, junto à massa, uma variável importante nas interações com o ar.

Como dito anteriormente, no planejamento da intervenção didática, o professor não considerou a resistência do ar como um fator importante. Por isso, percebemos, a partir dos dados do Quadro 5, que o pouco controle sobre as variáveis no experimento dificultou aos alunos a formulação de uma explicação que considerasse a resistência do ar sobre o movimento. Havia duas dicotomias: uma em relação às observações no vídeo em que as esferas eram vistas caírem juntas e na IE que registrou quedas em tempos diferentes; e outra em relação à não simultaneidade no abandono/influência da resistência do ar nos movimentos. Isso fez com que Lays recorresse à presença do professor, cuja intervenção está registrada no episódio de ensino do Quadro 6.

Quadro 6. Quarto episódio: transcrição da interação entre alunos e professor

\begin{tabular}{|c|c|c|c|}
\hline Turno & Fala & Descrição & Indicador de AC \\
\hline 84 & $\begin{array}{l}\text { Lays: } 0 \text { que a gente está } \\
\text { querendo saber é o que está } \\
\text { atuando: se é só a gravidade } \\
\text { ou se tem a resistência do ar. } \\
\text { Quando o vídeo passa a gente } \\
\text { acha que as duas bolinhas } \\
\text { alcançam o chão no mesmo } \\
\text { intervalo de tempo. E na foto } \\
\text { está mostrando que a bolinha } \\
\text { de menor massa atinge o } \\
\text { chão primeiro. }\end{array}$ & $\begin{array}{l}\text { Aqui surge a necessidade } \\
\text { de delimitação do } \\
\text { fenômeno da queda. } \\
\text { Isso porque a Imagem } \\
\text { Estroboscópica revelou } \\
\text { detalhes que não foram } \\
\text { perceptíveis no vídeo. }\end{array}$ & $\begin{array}{l}\text {-Seriação de } \\
\text { informações } \\
\text {-Organização } \\
\text { de informações } \\
\text {-Levantamento } \\
\text { de hipóteses } \\
\text { - Justificativa } \\
\text {-Previsão } \\
\text {-Explicação }\end{array}$ \\
\hline 85 & $\begin{array}{l}\text { Professor: Então por isso } \\
\text { vocês não chegaram num } \\
\text { consenso? }\end{array}$ & & \\
\hline
\end{tabular}




\begin{tabular}{|c|c|c|c|}
\hline 86 & $\begin{array}{l}\text { Lays: Não, é que a gente } \\
\text { chegou nesse consenso, que } \\
\text { pelo vídeo mostra uma coisa } \\
\text { e pela foto tá mostrando } \\
\text { outra. Então a gente não sabe } \\
\text { qual que está correta. }\end{array}$ & $\begin{array}{l}\text { A aluna explica o porquê } \\
\text { da dificuldade em } \\
\text { formular uma explanação. } \\
\text { Ela não sabe se formula a } \\
\text { explanação fundamentada } \\
\text { no vídeo ou na imagem } \\
\text { estroboscópica. }\end{array}$ & $\begin{array}{l}\text {-Organização } \\
\text { de informações } \\
\text {-Explicação }\end{array}$ \\
\hline 87 & $\begin{array}{l}\text { Professor: Por que será que } \\
\text { no vídeo a gente não percebe } \\
\text { que a menor cai primeiro? }\end{array}$ & $\begin{array}{l}\text { Nessa hora o professor } \\
\text { induz uma confiabilidade } \\
\text { maior para a IE }\end{array}$ & \\
\hline 88 & $\begin{array}{l}\text { Lays: Porque o intervalo de } \\
\text { tempo é bem curto, quase } \\
\text { insignificante. }\end{array}$ & $\begin{array}{l}\text { A aluna pensa na } \\
\text { possibilidade de } \\
\text { desconsiderar o pequeno } \\
\text { intervalo de tempo entre } \\
\text { as duas chegarem ao } \\
\text { chão. }\end{array}$ & $\begin{array}{l}\text {-Levantamento } \\
\text { de hipóteses } \\
\text {-Justificativa } \\
\text {-Explicação }\end{array}$ \\
\hline 89 & $\begin{array}{l}\text { Professor: Então é porque o } \\
\text { movimento é muito rápido e } \\
\text { nossos olhos não conseguem } \\
\text { perceber? }\end{array}$ & $\begin{array}{l}\text { Professor justifica porque } \\
\text { a IE é melhor para } \\
\text { observar o movimento. }\end{array}$ & \\
\hline 90 & Lays: Sim, não conseguem. & & $\begin{array}{l}\text {-Organização } \\
\text { de informações }\end{array}$ \\
\hline 91 & $\begin{array}{l}\text { Professor: E a partir da } \\
\text { imagem estroboscópica a } \\
\text { gente tem uma... }\end{array}$ & $\begin{array}{l}\text { Professor dá pausa para } \\
\text { que os alunos formulem } \\
\text { suas conclusões. }\end{array}$ & \\
\hline 92 & Lays: Detalhe. & A aluna conclui. & -Explicação \\
\hline 93 & $\begin{array}{l}\text { Professor: A gente vê mais } \\
\text { detalhes. }\end{array}$ & $\begin{array}{l}\text { Confirmação da fala da } \\
\text { aluna. }\end{array}$ & \\
\hline
\end{tabular}

Fonte: 0 autor, 2017.

Na interação dos alunos com o professor, percebemos uma predominância de indicadores associados à necessidade de entendimento da situação analisada (SASSERON; CARVALHO, 2008). Sem uma definição sobre qual recurso eles utilizariam para a formulação de uma explicação, se o vídeo ou a IE, ficou impossível prosseguir. Com a intervenção do professor, ficou definido que a IE oferecia, neste caso, mais informações sobre o movimento do que o vídeo da queda. Em contrapartida, o resultado evidenciado pela imagem divergia de todas as previsões. Na sequência, o professor propôs uma nova atividade para a turma na qual a esfera pequena da primeira atividade $\left(\mathrm{d}_{1}=2,4 \mathrm{~cm} \mathrm{e} \mathrm{m}_{1}=20 \mathrm{~g}\right)$ seria substituída por uma ainda menor $\left(d_{2}=1,6 \mathrm{~cm} \mathrm{e} \mathrm{m}_{2}=5,4 \mathrm{~g}\right)$. Apresentamos, a seguir, os resultados da segunda atividade. 


\section{PROPOSIC̣ÃO 2}

Para a proposição dois, a situação problema colocada foi a que se segue: na atividade 2 serão abandonadas duas esferas, uma de massa 5,4 g e diâmetro 1,6 cm, junto a uma grande de diâmetro 3,4 cm e massa 273 g. Solicito que vocês façam suas previsões sobre o movimento das esferas.

No Quadro 7 está a transcrição de um trecho da formulação da nova previsão.

Quadro 7. Quinto episódio de ensino

\begin{tabular}{|c|c|c|c|}
\hline Turno & Fala & Descrição & Indicador de AC \\
\hline 121 & $\begin{array}{l}\text { Lays: Cara, a previsão } \\
\text { é a mesma. }\end{array}$ & $\begin{array}{l}\text { A aluna se refere ao que ocorreu } \\
\text { na atividade } 1 \text {, ou seja que a menor } \\
\text { esfera cairia primeiro. }\end{array}$ & $\begin{array}{l}\text {-Levantamento } \\
\text { de hipóteses }\end{array}$ \\
\hline 122 & $\begin{array}{l}\text { Marcos: Quem é } \\
\text { mesma? }\end{array}$ & $\begin{array}{l}0 \text { aluno tenta compreender onde } \\
\text { está a diferença entre a atividade } \\
1 \text { e a } 2 \text {. }\end{array}$ & $\begin{array}{l}\text {-Classificação } \\
\text { de informações }\end{array}$ \\
\hline 123 & $\begin{array}{l}\text { João: Cara, massa } \mathrm{mP} \\
\text { é da pequena e } \mathrm{mG} \text { da } \\
\text { grande. }\end{array}$ & $\begin{array}{l}\text { O aluno explica que a esfera média } \\
\text { da atividade anterior foi substituída } \\
\text { por uma esfera pequena. }\end{array}$ & $\begin{array}{l}\text {-Seriação de } \\
\text { informações }\end{array}$ \\
\hline 124 & $\begin{array}{l}\text { Marcos: Que isso, } \\
\text { cara! A diferença de } \\
\text { uma massa pra outra é } \\
\text { muito grande! }\end{array}$ & $\begin{array}{l}\text { O aluno refuta a previsão de } \\
\text { Lays em função do aumento } \\
\text { considerável na diferença entre } \\
\text { as massas e os diâmetros das } \\
\text { esferas. }\end{array}$ & $\begin{array}{l}\text {-Classificação } \\
\text { de informações }\end{array}$ \\
\hline 125 & $\begin{array}{l}\text { Carla: Cara, eu } \\
\text { continuo achando que } \\
\text { a previsão é a mesma. }\end{array}$ & $\begin{array}{l}\text { A aluna refere à previsão que ela } \\
\text { havia feito para a atividade 1, que } \\
\text { ambas cairiam juntas (turno 19). }\end{array}$ & $\begin{array}{l}\text {-Levantamento } \\
\text { de hipóteses }\end{array}$ \\
\hline 126 & $\begin{array}{l}\text { Marcos: Incluindo a } \\
\text { resistência do ar eu } \\
\text { acho que a pesada } \\
\text { chega mais rápido. }\end{array}$ & $\begin{array}{l}\text { Marcos sustenta a hipótese } \\
\text { aristotélica que corpos pesados } \\
\text { caem mais rapidamente que } \\
\text { corpos leves. }\end{array}$ & $\begin{array}{l}\text {-Organização } \\
\text { de informações } \\
\text {-Levantamento } \\
\text { de hipóteses }\end{array}$ \\
\hline 127 & $\begin{array}{l}\text { Carlos: Não porque, no } \\
\text { caso, a gente não tem } \\
\text { essa informação. }\end{array}$ & & $\begin{array}{l}\text {-Organização } \\
\text { de informações }\end{array}$ \\
\hline 128 & $\begin{array}{l}\text { Marcos: Então, é só a } \\
\text { previsão. }\end{array}$ & $\begin{array}{l}\text { O aluno atenta para o fato de } \\
\text { que eles estão formulando } \\
\text { uma previsão, quando podem } \\
\text { livremente dizer o que eles acham } \\
\text { que ocorrerá }\end{array}$ & $\begin{array}{l}\text {-Classificação } \\
\text { de informações }\end{array}$ \\
\hline
\end{tabular}

Fonte: 0 autor, 2017. 
Os dados mostram que as previsões dos alunos para a segunda atividade foram semelhantes às previsões da primeira atividade, ou seja, previsões considerando a não simultaneidade no abandono e previsões considerando a resistência do ar. Porém, no turno 127, pela primeira vez o aluno Carlos se manifesta e sua fala indica que o experimento não permite que eles tenham informações para considerar a resistência do ar. Tudo indica que seu intuito foi delimitar a observação, pois saber o que se considerar numa observação é tão importante quanto saber o que se deve desconsiderar.

$\mathrm{Na}$ sequência, o professor exibiu o vídeo com a queda das esferas e, assim como na atividade anterior, a observação feita a partir do vídeo indicou que as esferas atingiram o chão no mesmo instante. A IE exibida (Figura 7), diferentemente das quedas na atividade anterior, mostrou que nesse caso as esferas tiveram movimentos parecidos. Para esta atividade percebemos que os alunos não se limitaram à separação entre as etapas de Observação e de Explanação propostas na metodologia POE. Isso indica que, numa atividade investigativa, a estratégia POE é uma boa opção para o planejamento docente, mas que não devemos esperar que os alunos respeitem os limites entre as etapas, pois aprender no ensino por investigação é uma prática essencialmente livre da mesma forma que livres são os pensamentos.

Figura 7. IE

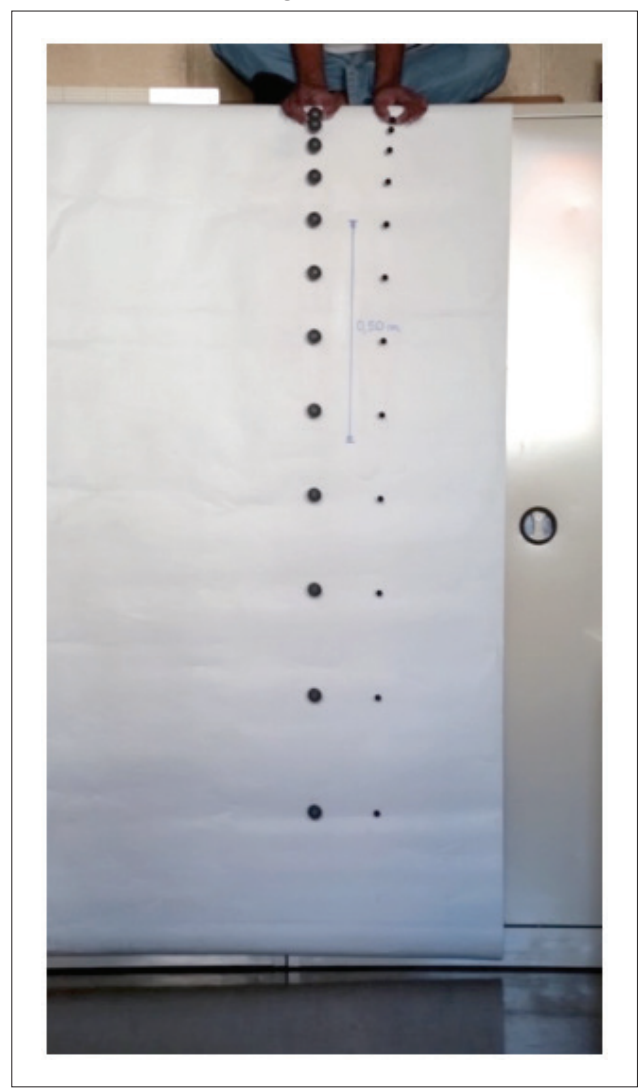

Fonte: 0 autor, 2017. 
As diferenças nos comportamentos dos movimentos de queda das esferas nas atividades 1 e 2 trouxeram novamente a possibilidade da não simultaneidade do abandono na primeira atividade citada por Carla no turno 65 do Quadro 4, mas agora essa possibilidade foi colocada por Lays no turno 146 do Quadro 8. Percebemos nesse turno que a aluna busca corroborar as duas hipóteses levantadas no grupo: a de que não houve simultaneidade no abandono e a de que existe resistência do ar. É importante ressaltar que em nenhum momento essa aluna manifestou algum conhecimento prévio sobre a queda dos corpos e que sua interação com o fenômeno se iniciou empiricamente (turnos 18, 20 e 22 do Quadro 3). No turno 64 do Quadro 4, a aluna questionou as diferentes observações sobre os movimentos na atividade 1 em relação ao que se via no vídeo e na IE, quando recorreu ao professor. Uma vez que a intervenção docente nos turnos 85, 87 e 89 do Quadro 6 a fez reconhecer que na IE há mais “riqueza de detalhes” (turno 92, Quadro 6), Lays previu, a partir do único controle disponível no experimento (o fato das duas atividades terem sido realizadas no mesmo local), que a esfera menor cairia primeiro assim como na atividade 1 (turno 121, Quadro 7). Contudo, sua previsão não se confirmou na observação.

Sob outra perspectiva, diferente de Carla e Carlos, João e Marcos ainda consideravam os efeitos da resistência do ar sobre os movimentos. No turno 144 do Quadro 8, Lays chama a atenção do grupo para a necessidade de considerar ou não a resistência do ar e, a partir daí, discute com Carla sobre desprezar ou não tal efeito. $\mathrm{Na}$ opinião da discente, tal efeito somente pode ser desprezado no vácuo (turno 146). Assim, após a interação com Carla, Lays conclui que, ainda que se considere a resistência do ar, essa interação estaria controlada nas duas atividades e as esferas deveriam ter comportamentos semelhantes. Por fim, no turno 148, ela conclui seu argumento de que não houve simultaneidade no abandono das esferas na atividade 1 , mas que existe essa simultaneidade na atividade 2.

Até aqui a análise dos dados mostra um envolvimento dos alunos na solução de problemas resultantes de uma situação real, e que deixou de ser apenas a queda dos corpos, pois passou a envolver a forma como os corpos foram abandonados e os recursos utilizados para a observação dos movimentos. A presença dos indicadores de AC mostra que o conhecimento científico está sendo construído, e essa construção ocorre entre os pares, ou seja, socialmente, onde alunos com níveis de conhecimentos diferentes, num mesmo grupo, interagem para a solução de um problema proposto (DRIVER, 1999). 
Quadro 8. Sexto episódio de ensino

\begin{tabular}{|c|c|c|c|}
\hline Turno & Fala & Descrição & Indicador de AC \\
\hline 144 & $\begin{array}{l}\text { Lays: Mas aí eu quero } \\
\text { saber, tem ou não } \\
\text { resistência? Cara, tem que } \\
\text { ter alguma diferença. As } \\
\text { duas [experiências] foram } \\
\text { feitas no mesmo lugar! }\end{array}$ & $\begin{array}{l}\text { A aluna busca organizar a } \\
\text { discussão junto ao grupo }\end{array}$ & $\begin{array}{l}\text {-Organização de } \\
\text { informações } \\
\text {-Levantamento } \\
\text { de hipóteses } \\
\text {-Justificativa }\end{array}$ \\
\hline 145 & $\begin{array}{l}\text { Carla: Cara, olha só, } \\
\text { despreza a resistência do ar. }\end{array}$ & $\begin{array}{l}\text { Carla tenta simplificar a } \\
\text { situação experimental, para } \\
\text { ser mais fácil aplicar um } \\
\text { modelo físico. }\end{array}$ & $\begin{array}{l}\text {-Levantamento } \\
\text { de hipóteses } \\
\text { - Justificativa } \\
\text {-Previsão } \\
\text {-Explicação }\end{array}$ \\
\hline 146 & $\begin{array}{l}\text { Lays: Não, não tem como } \\
\text { desprezar a resistência } \\
\text { do ar. Como? Só se for no } \\
\text { vácuo! Eu acho que ele } \\
\text { soltou a primeira bolinha } \\
\text { em instantes diferentes. } \\
\text { No primeiro vídeo. A } \\
\text { bolinha foi solta em } \\
\text { instante diferente. }\end{array}$ & $\begin{array}{l}\text { Lays apercebe-se que não } \\
\text { pode simplificar a situação } \\
\text { experimental e propõe uma } \\
\text { explicação para a atividade } 1 .\end{array}$ & $\begin{array}{l}\text {-Organização de } \\
\text { informações } \\
\text {-Raciocínio } \\
\text { lógico } \\
\text {-Levantamento } \\
\text { de hipóteses } \\
\text {-Explicação } \\
\text {-Justificativa }\end{array}$ \\
\hline 147 & Carla: Por quê? & & \\
\hline 148 & $\begin{array}{l}\text { Lays: As duas experiências } \\
\text { foram feitas no mesmo } \\
\text { local, com resistência do } \\
\text { ar, porque se não fosse } \\
\text { a resistência do ar seria } \\
\text { no vácuo. Tem a força } \\
\text { da gravidade atuando } \\
\text { e chegaram no mesmo } \\
\text { intervalo de tempo. Então } \\
\text { ele soltou a bolinha no } \\
\text { primeiro vídeo antes. }\end{array}$ & $\begin{array}{l}\text { Lays compara as condições } \\
\text { das duas atividades e projeta } \\
\text { uma explicação global para o } \\
\text { observado. }\end{array}$ & $\begin{array}{l}\text {-Classificação } \\
\text { de informação } \\
\text {-Teste de } \\
\text { hipóteses } \\
\text {-Explicação } \\
\text {-Justificativa } \\
\text {-Previsão } \\
\text {-Raciocínio } \\
\text { lógico } \\
\text {-Raciocínio } \\
\text { proporcional }\end{array}$ \\
\hline
\end{tabular}

Fonte: 0 autor, 2017.

Nessa altura da intervenção, a explicação da Lays, porta-voz do grupo para o fenômeno em estudo, considerava tanto a não simultaneidade no abandono quanto a resistência do ar atuando igualmente em todos os corpos. $\mathrm{Na}$ transcrição do sétimo episódio de ensino (Quadro 9), verificamos que a orientação docente foi no sentido de os alunos sugerirem uma forma de confirmar o argumento que Lays utilizou no turno 148. Os alunos utilizaram a própria IE para defender o 
argumento e, no turno 157 do Quadro 9, Lays sugere que as posições variam analogamente nas duas trajetórias. No turno 161, Bianca, em sua primeira interação com o grupo, observa a equivalência entre as distâncias percorridas nos intervalos de tempo correspondentes pelas duas esferas na atividade 1 e indica uma forma de comprovar essa observação a partir da medição dessas distâncias com a régua (medição feita na imagem projetada pelo datashow), corroborando a sugestão de Lays, o que levou Carla a confirmar, no turno 162, sua previsão inicial de que as esferas não foram abandonadas simultaneamente.

Quadro 9. Sétimo episódio de ensino

\begin{tabular}{|c|c|c|c|}
\hline Turno & Fala & Descrição & Indicador de AC \\
\hline 156 & $\begin{array}{l}\text { Professor: Existe alguma forma } \\
\text { de comprovar nessa primeira } \\
\text { fotografia que eu não consegui } \\
\text { abandoná-las simultaneamente? }\end{array}$ & & \\
\hline 157 & Lays: Posição? & & $\begin{array}{l}\text {-Levantamento } \\
\text { de hipóteses }\end{array}$ \\
\hline 158 & Professor: Pelas distâncias? & & \\
\hline 159 & Lays: Sim. & & $\begin{array}{l}\text {-Classificação } \\
\text { de informações }\end{array}$ \\
\hline 160 & $\begin{array}{l}\text { Professor: Você quer dizer essas } \\
\text { distâncias? }\end{array}$ & $\begin{array}{l}\text { Professor aponta } \\
\text { para as distâncias } \\
\text { percorridas em } \\
\text { intervalos de tempo } \\
\text { correspondentes. }\end{array}$ & \\
\hline 161 & $\begin{array}{l}\text { Bianca: Não, assim oh! Você vê } \\
\text { que os espações vão aumentando } \\
\text { gradativamente. Tanto da direita } \\
\text { quanto da esquerda. São iguais. } \\
\text { Daí você percebe que... }\end{array}$ & $\begin{array}{l}\text { Aluna vai à tela de } \\
\text { projeção. }\end{array}$ & $\begin{array}{l}\text {-Organização de } \\
\text { informações } \\
\text {-Teste de } \\
\text { hipóteses } \\
\text {-Explicação } \\
\text {-Justificativa } \\
\text {-Previsão } \\
\text {-Raciocínio } \\
\text { lógico } \\
\text {-Raciocínio } \\
\text { proporcional }\end{array}$ \\
\hline 162 & $\begin{array}{l}\text { Carla: Você soltou uma primeiro } \\
\text { que a outra. }\end{array}$ & $\begin{array}{l}\text { Prova baseada em } \\
\text { dados. }\end{array}$ & -Justificativa \\
\hline
\end{tabular}

Fonte: 0 autor, 2017. 
Nessa fase, entrou espontaneamente em cena um outro aspecto interessante da cultura científica, que foi a tentativa de generalização do que foi observado nas atividades. No turno 175, a palavra "lei" é falada pela primeira vez durante a intervenção. Nesse episódio a formulação da "lei" é feita sem uma intervenção docente que vá além de uma provocação, como no turno 176 do Quadro 10. Nos turnos subsequentes, a formulação dessa "lei" é feita pelos próprios alunos, ainda que eles desconfiem de que esse seja mesmo um comportamento regular da natureza.

Quadro 10. Oitavo episódio de ensino

\begin{tabular}{|c|c|c|c|}
\hline Turno & Fala & Descrição & Indicador de AC \\
\hline 175 & $\begin{array}{l}\text { Lays: Eu acho que é uma lei. Tem } \\
\text { uma lei que se aplica. }\end{array}$ & $\begin{array}{l}\text { Tentativa de } \\
\text { generalização }\end{array}$ & $\begin{array}{l}\text {-Classificação } \\
\text { de informações } \\
\text {-Levantamento } \\
\text { de hipóteses }\end{array}$ \\
\hline 176 & Professor: Qual lei? & & \\
\hline 177 & Lays: Eu não sei qual é. & & \\
\hline 178 & $\begin{array}{l}\text { Carla: Eu não sei se exatamente } \\
\text { isso, mas dois corpos de mesma } \\
\text { massa tendem a chegar ao chão } \\
\text { no mesmo instante de tempo. }\end{array}$ & $\begin{array}{l}\text { Formulação de } \\
\text { generalização. }\end{array}$ & $\begin{array}{l}\text {-Explicação } \\
\text {-Raciocínio } \\
\text { lógico }\end{array}$ \\
\hline 179 & $\begin{array}{l}\text { Carlos: Mas as massas são } \\
\text { diferentes }\end{array}$ & $\begin{array}{l}\text { Refutação à } \\
\text { generalização. }\end{array}$ & $\begin{array}{l}\text {-Organização de } \\
\text { informações }\end{array}$ \\
\hline 180 & Carla: Mas ele perguntou a lei & & $\begin{array}{l}\text {-Organização de } \\
\text { informações }\end{array}$ \\
\hline 181 & $\begin{array}{l}\text { Lays: Mas o nome da lei eu não sei. } \\
\text { Lei gravitacional? }\end{array}$ & & $\begin{array}{l}\text {-Classificação } \\
\text { de informações }\end{array}$ \\
\hline
\end{tabular}

Fonte: 0 autor, 2017.

O debate prosseguiu: de um lado, os alunos que traziam consigo a ideia de resistência do ar sobre os movimentos de queda tentavam salvar o fenômeno, argumentando que as esferas mais pesadas deveriam cair primeiro; do outro lado, os que teriam aceitado a concepção de que a resistência atuava igualmente sobre todas as esferas e que a diferença nas quedas se deu por conta dos diferentes instantes de abandonos. Ambos os lados tentavam confirmar suas hipóteses e, dessa maneira, os alunos solicitaram que o vídeo fosse reproduzido em câmera lenta. Por ocasião da reprodução, todos verificaram que não houve simultaneidade no abandono na primeira atividade, ainda que numa fração de décimos de segundos. Por isso a diferença no tempo de queda fora perceptível apenas na IE, e não no vídeo reproduzido em tempo real. 
A partir da observação do vídeo em câmera lenta, os alunos ficaram mais confiantes em formularem um argumento (que eles chamaram de lei), conforme transcrito no turno 193 do Quadro 11. Nesse mesmo turno, Lays coloca as condições de contorno para que a "lei" da Carla seja válida.

Quadro 11. Nono episódio de ensino

\begin{tabular}{|c|c|c|c|}
\hline Turno & Fala & Descrição & Indicador de AC \\
\hline 192 & $\begin{array}{l}\text { Professor: Eu quero saber se } \\
\text { a lei a que a Carla se refere é } \\
\text { válida ou não é? }\end{array}$ & $\begin{array}{l}\text { O professor se refere à fala } \\
\text { da aluna no turno } 178 \text { do } \\
\text { Quadro } 10\end{array}$ & \\
\hline 193 & $\begin{array}{l}\text { Lays: Sim, é a lei da gravidade. } \\
\text { Mas essa lei só se aplica } \\
\text { se você soltar os corpos ao } \\
\text { mesmo tempo. Porque se você } \\
\text { não soltar vai acontecer o que } \\
\text { aconteceu ali, uma vai chegar } \\
\text { primeiro que a outra. }\end{array}$ & $\begin{array}{l}\text { A aluna impõe condições } \\
\text { de contorno para que a } \\
\text { generalização seja válida }\end{array}$ & $\begin{array}{l}\text {-Seriação de } \\
\text { informações } \\
\text {-Explicação } \\
\text { - Justificativa }\end{array}$ \\
\hline 194 & $\begin{array}{l}\text { Professor: Isso é condição } \\
\text { primordial, certo? }\end{array}$ & & \\
\hline 195 & $\begin{array}{l}\text { Lays: Sim, é uma regra, mas } \\
\text { há exceções. }\end{array}$ & $\begin{array}{l}\text { Lays evidencia o caráter } \\
\text { geral da lei, mas } \\
\text { admite a exceção como } \\
\text { cientificamente aceite, } \\
\text { introduzindo práticas do } \\
\text { senso comum. }\end{array}$ & $\begin{array}{l}\text {-Explicação } \\
\text {-Organização } \\
\text { de informações } \\
\text {-Justificativa }\end{array}$ \\
\hline
\end{tabular}

Fonte: 0 autor, 2017.

Ainda não havia ficado claro se as exceções às quais Lays se referiu no turno 195 do Quadro 11 incluíam as diferenças entre as massas e diâmetros das esferas. Como no turno 148 do Quadro 8 a aluna considerou a resistência do ar uma constante que não dependia das características das esferas, em vez de desconsiderar a massa no problema de queda livre, o professor achou necessário intervir para formalizar a interpretação do fenômeno.

Assim, na finalização (etapa 6, Quadro 2), a sugestão dada pelo professor para verificar se as massas e os diâmetros das esferas influíam nos respetivos movimentos foi no sentido de verificar graficamente como variam as posições com o tempo. Para tal, o professor demonstrou como o software Tracker permite fazer medidas das posições em cada instante do movimento de cada uma das esferas e, com esses valores, esboçar os gráficos das posições verticais em função do tempo. Com os dados organizados em tabela e gráfico, o professor fez o ajuste parabólico para que os alunos comparassem as equações dos gráficos, à luz do modelo físico que lhes foi apresentado.

$\mathrm{Na}$ Figura 8 podem ser observados os gráficos das curvas ajustadas aos pontos medidos para os movimentos das duas esferas da primeira atividade, aquela 
em que houve diferença nos tempos de queda. A pequena discrepância entre os parâmetros A e C das duas equações (respectivamente $0,16 \%$ e $0,90 \%$ relativamente ao valor-padrão de $4,905 \mathrm{~m} / \mathrm{s}^{2}$ ), indicam que as esferas estiveram submetidas à mesma aceleração (parâmetro A) e partiram praticamente da mesma posição inicial (parâmetro C). Por outro lado, o parâmetro B, associado à velocidade inicial, mostra que a velocidade inicial da esfera grande (gráfico da Figura 8b), é 25\% discrepante em relação à velocidade inicial da esfera Média (gráfico da Figura 8a). Portanto, confirma-se que na atividade 1, as esferas saíram da mesma posição inicial, foram submetidas à mesma aceleração, porém abandonadas em instantes diferentes.

Figura 8. Gráfico da posição em função do tempo para a esfera média (a) e para a esfera grande (b)
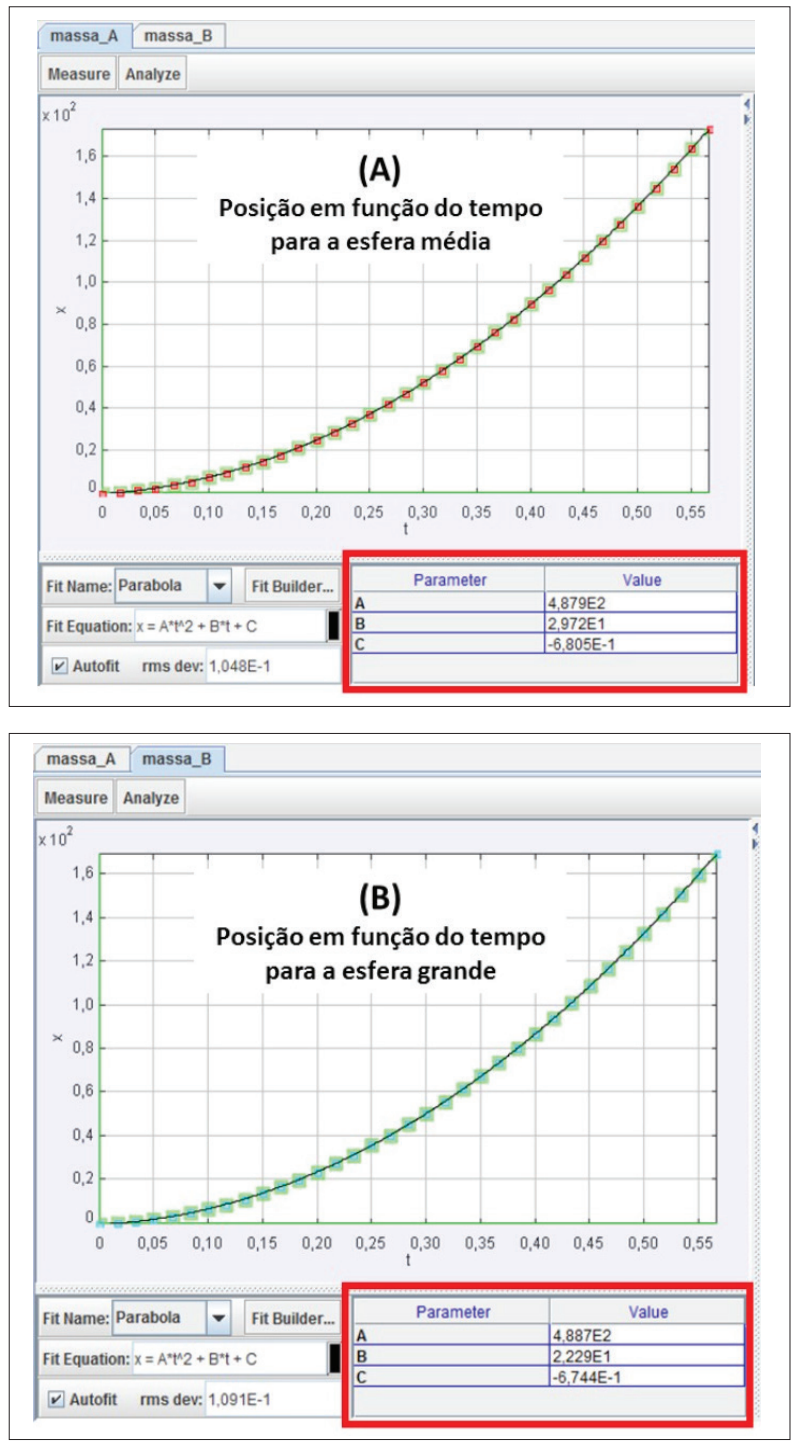

Legenda: As unidades fundamentais de medida são 0 centímetro e 0 segundo.

Fonte: 0 autor, 2017. 
Como a intervenção ocorreu em uma aula dentro do planejamento de um curso de Física da primeira série, a finalização possibilitou a continuidade do aprendizado nas próximas intervenções, que não seriam objeto de pesquisa, com a vantagem de os alunos terem iniciado seus estudos numa situação concreta para chegar à interpretação abstrata do modelo físico.

\section{CONSIDERAC̣ÕES FINAIS}

Em nossa metodologia de ensino, as imagens estroboscópicas foram utilizadas para a observação pormenorizada do movimento, possibilitando uma confrontação entre os conhecimentos prévios dos alunos e o que eles constataram à luz da observação, que desencadeou as interações discursivas para a elaboração de uma explicação a partir do que foi observado. Por fim, a videoanálise contribuiu para sistematizar o conhecimento com a modelagem fenomenológica feita online e on-time. Assim, a investigação do movimento de queda dos corpos pelos alunos a partir da exibição de um vídeo previamente gravado, intermediada pelas imagens estroboscópicas e a videoanálise, evidenciou que os recursos de vídeo são ferramentas com potencial para um ensino por investigação.

Nos resultados apresentados percebemos que toda a construção de explicações para o que foi observado se deu a partir das interações discursivas, com afirmações fundamentadas em justificativas e julgamentos construídos logicamente pelos pares. Este resultado nos mostra que a proposta de ensino da queda dos corpos por um processo de investigação, com os recursos de vídeo, tem potencial para envolver os alunos na solução do problema proposto. Por outro lado, também verificamos a presença de indicadores de alfabetização científica em quase todas as falas dos alunos ao longo da intervenção. Com isso, confirmamos nossa hipótese de que há potencial nesses recursos para a promoção da alfabetização científica.

Dos indicadores de alfabetização científica presentes nas falas dos alunos, aproximadamente metade estavam relacionados ao entendimento da situação analisada (SASSERON; CARVALHO, 2008). Atribuímos esse resultado ao fato de que, em nossa proposta, utilizamos os recursos de vídeo para a resolução de um problema real, para o qual existem muitas variáveis e interações. Em nosso caso, isso ficou evidente na ocasião do planejamento da intervenção didática. Inicialmente, na realização das filmagens das esferas em queda a partir do abandono manual, as variáveis pensadas foram aquelas de natureza extensiva, como a massa, o diâmetro e o volume. Além dessas variáveis, também foram pensadas a interação gravitacional entre a massa das esferas e a massa da Terra, além da interação resultante do contato entre a esfera e o ar atmosférico, ou seja, a resistência do ar, ainda que com efeito desprezível. Assim, não estava presente na ocasião da filmagem para a produção do material didático a não simultaneidade no abandono. Apesar desse efeito não ser observável quando o vídeo é reproduzido em tempo real, o potencial de observação detalhada do movimento com as imagens estroboscópicas e a videoanálise - para além do que normalmente se vê - fez com que a delimitação de variáveis/interações inicialmente pensadas fosse ampliada ainda na fase do planejamento da intervenção. 
Do exposto acima, chegamos a duas conclusões: a primeira é que, para a articulação de uma proposta de ensino por investigação de um problema real, é importante que o docente tenha em mente todas as interações existentes no fenômeno e, com isso, possa estar melhor preparado para os caminhos possíveis para se atingir o objetivo de ensino; a segunda é que, quando se considera todas as interações possíveis num fenômeno a ser investigado, boa parte do tempo disponível será utilizado para a compreensão da situação analisada.

Outra conclusão é que, como a metodologia de ensino utilizada no planejamento da intervenção didática considera referenciais que são capazes de promover a interatividade entre os alunos e o fenômeno em estudo, as SEI e a estratégia POE, em grande parte do tempo as interações discursivas ocorreram entre os alunos, com poucas intervenções docentes que, quando ocorreram, foram no sentido de fomentar ainda mais as interações discursivas e a formulação de argumentos dos discentes. Diferente do que ocorre no laboratório formal, uma atividade prática capaz de desafiar as concepções prévias dos alunos, encorajandoos a reorganizarem suas teorias pessoais, que considera a inter-relação entre fatores da experiência pessoal, da linguagem e da socialização de forma interativa e colaborativa (DRIVER ET AL, 1999), fomenta uma aprendizagem entre pares e a construção do conhecimento científico. Percebemos aqui uma característica importante na proposta de ensino por investigação: a mudança do papel docente de transmissor do conhecimento pronto, construído pelas gerações anteriores, para um papel de promotor do conhecimento produzido in-loco.

Por fim, o fato de os recursos terem origem em vídeos previamente produzidos nos permite inferir que a gama de possibilidades de movimentos a serem filmados e depois transformados em material didático é grande, o que abre um campo de oportunidades futuras tanto para o Ensino de Ciências quanto para a Pesquisa em Educação em Ciências.

\section{AGRADECIMENTOS}

O trabalho foi realizado com apoio da Coordenação de Aperfeiçoamento de Pessoal de Nível Superior - Brasil (CAPES) - Código de Financiamento 001. Os autores agradecem ao Campus Nilópolis do IFRJ pelo incentivo à pesquisa.

\section{REFERÊNCIAS}

BASSOLI, F. Atividades práticas e o ensino-aprendizagem de ciência(s): mitos, tendências e distorções. Ciência \& Educação. v. 20, n. 3, p. 579-593, 2014.

BROWN, D. e COX, A.J. Innovative Uses of Video Analysis. The Physics Teacher, v.47, p.145-150, 2009.

BROWN, D. Video modeling: combining dynamic model simulations with traditional video analysis. American Association of Physics Teachers (AAPT) Summer Meeting, Edmonton, 2008. (Software disponível em www.cabrillo.edu/ dbrown/tracker/. Acesso em: 28 de nov. 2017) 
CANIATO, R. Mecânica: Projeto Brasileiro para o Ensino de Física. 1 Ed. Campinas: Fundação tropical de pesquisas e tecnologia, 1979.

CANIATO, R. Rodolpho Caniato. Campinas, SP: 19, jul. 2011. Disponível em: < http://rodol phocaniato.blogspot.com.br/2011/07/blog-post.html>. Acesso em: 22 nov. 2017.

CARVALHO, A. M. P. O ensino de Ciências e a proposição de Sequências de Ensino Investigativas. In: CARVALHO, A. M. P. (org.) Ensino de Ciências por investigação: condições para implementação em sala de aula. São Paulo: Ed. Cencage learning, cap.1, p.1-20 2013.

CARvalHO, P.S., et al. How to Use a Candle to Study Sound Waves. The Physics Teacher, 51, p. 398-399, 2013.

CARVALHO, A.M.P.; TINOCO, S.C. O Ensino de Ciências como 'enculturação'. In: CATANI, D.B.; VICENTINI, P.P., (org.). Formação e autoformação: saberes e práticas nas experiências dos professores. São Paulo: Escrituras, p.251-255. 2006.

DIAS, M. A.; BARROS, S. S.; AMORIM, H. S. Produção de fotografias estroboscópica sem lâmpada estroboscópica. Caderno Brasileiro de Ensino de Física, v. 26, n.3, p.492-513, 2009.

DIAS, M. A., CARVALHO, P. S. e VIANNA, D. M. The Image Modeling for teaching Newton's Laws with the Ollie Trick. Physics Education, 51(4), p.1-6, 2016.

DiAS, M. A., CARVALHO, P. S. e RODRIGUES, M. How to determine the Centre of Mass of bodies from Image Modelling. Physics Education, v.51, n.2, p.1-7, 2016.

DIAS, M.A., et al. The behaviour of the Centre of Mass in a Ballerina while performing a Grand Jeté. Physics Education, 2017. Aceito para publicação.

DRIVER, R., et al. Construindo conhecimento científico na sala de aula. Química nova na escola, n. 9 , p.31-40, 1999.

JESUS, V.L.B.; BARROS, M.A.J. As múltiplas faces da dança dos pêndulos. Revista Brasileira de Ensino de Física, v.36, n.4, 2014.

JESUS, V.L.B.; SASAKI, D.G.G. O experimento didático do lançamento horizontal de uma esfera: Um estudo por Videoanálise. Revista Brasileira de Ensino de Física, v. 37, n.1, 2015.

KEARNEY, M. Classroom Use of Multimedia-Supported Predict-Observe-Explain Tasks in a Social Constructivist Learning Environment. Research in Science Education, v.34, p.427-453, 2004.

KUÇUKOZER, H. The effects of 3D computer modelling on conceptual change about seasons and phases of the Moon. Physics Education, v.43, p.632-636, 2008.

LEMKE, J. L. Investigar para el futuro de la educación científica: novas formas de aprender, novas formas de vivir. Enzeñanza de lãs ciências, v.24, p.5-12, 2006. 
MALHEIRO, J. M. S. e FERNANDES, P. O recurso ao trabalho experimental e investigativo: percepções de professores de ciências. Investigações em ensino de ciências, v.20, n.1, p.79-96, 2015.

PHYSICAL SCIENCE STUDY COMMITTEE. Física: Parte I. São Paulo: Editora Universidade de Brasília, 1965.

RAKKAPAO, S. et al. Evaluation of POE and instructor-led problem-solving approaches integrated into force and motion lecture classes using a model analysis technique. European Journal of Physics, v.35, p.1-10, 2014.

RODRIGUES, M. e CARVALHO, P. S. Teaching optical phenomena with Tracker. Physics Education, v.49, n.6, p.671-677, 2014.

SANTOS, R. J. e SASAKI, D. G. G. Uma metodologia de aprendizagem ativa para o ensino de mecânica em educação de jovens e adultos. Revista Brasileira de Ensino de Física, v. 37, n.3, 2015.

SASSERON, L. H.; CARVALHO, A. M. P. Almejando a alfabetização científica no ensino fundamental: a proposição e a procura de indicadores do processo. Investigações em Ensino de Ciências, v.13, n.3, p.333-352, 2008.

SASSERON, L. H.; CARVALHO, A. M. Construindo argumentação na sala de aula: a presença do ciclo argumentativo, os indicadores de alfabetização científica e o padrão de toulmin. Ciência $\boldsymbol{\&}$ Educação, v. 17, n. 1, p. 97-114, 2011.

TAO, P.K.; GUNSTONE, R. F. The Process of Conceptual Change in Force and Motion during Computer-Supported Physics Instruction. Journal of Research In Science Teaching v.36, n.7, p.859-882, 1999.

WHITE, R.; GUNSTONE, R., Probing Understanding. New York: Falmer Press, 1992.

\section{Submetido em 17/06/2017 \\ Aprovado em 19/12/2017}

\section{Contato:}

Instituto Federal do Rio de Janeiro

Campus Nilópolis

Rua Cel. Délio Menezes Porto, 1045 - Centro,

CEP 26.530-060 - Nilópolis, RJ - Brasil 